\title{
Wykrywanie mykoplazm urogenitalnych w próbkach klinicznych
}

\begin{abstract}
STRESZCZENIE
$\mathbf{M}$ ykoplazmy urogenitalne to przedstawiciele rodzajów Mycoplasma i Ureaplasma, które są mikroorganizmami uznawanymi zarówno za komensalne, jak i patogenne. Złotym standardem wykrywania ich $w$ próbkach klinicznych jest hodowla i identyfikacja w oparciu o testy biochemiczne. Metoda ta jest jednak czasochłonna i mało specyficzna. Detekcja mykoplazm z wykorzystaniem PCR pozwala na przyporządkowanie nie tylko do rodzaju, ale także do gatunku. $W$ tej pracy analizie poddano 100 próbek klinicznych w celu identyfikacji M. hominis, M. genitalium, U. parvum i U. urealyticum, z wykorzystaniem zarówno metod biochemicznych, jak i molekularnych. Przedstawione wyniki potwierdzają małą specyficzność testów biochemicznych oraz większą skuteczność detekcji poszczególnych gatunków z wykorzystaniem metod molekularnych.
\end{abstract}

\section{WSTĘP}

Mikroorganizmy określane jako mykoplazmy to eubakterie klasy Mollicutes (rodzina Mycoplasmataceae, rodzaj Mycoplasma i Ureaplasma), najmniejsze znane samoreplikujące się organizmy. Wykazują one charakterystyczne cechy, takie jak brak ściany komórkowej, rozmiar komórek w granicach $0,3-0,8 \mu \mathrm{m}$ oraz niewielki genom $(0,58-2,20 \mathrm{Mb})[1,2]$. Jak dotąd zidentyfikowano ok. 200 gatunków mykoplazm, z których 17 związanych jest z człowiekiem. Kolonizują one głównie błony śluzowe dróg oddechowych i moczo-płciowych [3]. Dwa gatunki z rodzaju Mycoplasma - M. hominis i M. genitalium oraz dwa z rodzaju Ureaplasma - U. parvum i U. urealyticum wchodzą $\mathrm{w}$ skład mikrobioty pochwy i nazywane są mykoplazmami genitalnymi (lub urogenitalnymi). Ich obecność w biocenozie pochwy zależy od wieku, poziomu hormonów, aktywności seksualnej i ciąży [4]. Mykoplazmy genitalne są organizmami komensalnymi, jednak mogą odgrywać ważną rolę w patologii układu moczo-płciowego. Najczęściej właściwości chorobotwórcze przypisuje się Mycoplasma hominis i Ureaplasma urealyticum, pojawia się jednak coraz więcej doniesień na temat chorobotwórczości M. genitalium, a i rola U. paroum nie jest do końca jasna. Wiele wskazuje, że mykoplazmy urogenitalne związane są z przypadkami nieswoistych zapaleń dróg moczo-płciowych tj. nierzeżączkowe zapalenie cewki moczowej (NGU). Bakterie te mogą być także przyczyną powikłań, takich jak poronienie czy przedwczesny poród, ale również problemy z płodnością. Możliwe jest także zakażenie na drodze wertykalnej, co prowadzi do infekcji dolnych dróg oddechowych lub zespołów zaburzeń oddechowych u noworodków $[5,6]$.

Narządy rodne kobiet znacznie częściej skolonizowane są przez Ureaplasma spp. w porównaniu do gatunków z rodzaju Mycoplasma. Dane epidemiologiczne wskazują, że blisko $90 \%$ aktywnych seksualnie zdrowych kobiet jest nosicielkami ureaplazm, natomiast $M$. hominis występuje u $20-50 \%$, a M. genitalium u zaledwie 5\%. Jednoczesna kolonizacja więcej niż jednym gatunkiem mykoplazm jest również powszechna [7-13].

Potwierdzenie obecności mykoplazm urogenitalnych w próbkach klinicznych wymaga badań laboratoryjnych. Atypowa budowa komórkowa mykoplazm czyni je jednak trudnymi nie tylko $w$ wykrywaniu, ale także $w$ identyfikacji. Niewielkie rozmiary komórki i brak ściany komórkowej uniemożliwia bezpośrednią diagnostykę z materiału klinicznego, poprzez np. wykonanie preparatu barwionego metodą Grama. Techniki hodowlane wymagają zaś podłoży selektywnych oraz inkubacji w warunkach mikroaerofilnych [14]. Kliniczne testy diagnostyczne stosowane rutynowo, oparte na charakterystyce biochemicznej, wykorzystują reakcje kolorymetryczne. Umożliwiają one wykrywanie mykoplazm w próbie badanej oraz jednoczesne określenie ich lekowrażliwości. Ta ostatnia cecha jest szczególnie istotna ze względu na szeroką oporność naturalną tych drobnoustrojów np. wobec antybiotyków

\section{dr Sylwia Andrzejczak- Grządko $^{1 \rrbracket,}$}

\section{mgr Izabela Dolińska²}

${ }^{1}$ Katedra Mikrobiologii i Genetyki, Wydział Nauk Biologicznych, Uniwersytet Zielonogórski

${ }^{2}$ Zakład Diagnostyki Laboratoryjnej, Szpital Uniwersytecki im. K. Marcinkowskiego w Zielonej Górze

https://doi.org/10.18388/pb.2019_273

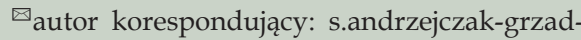
ko@wnb.uz.zgora.pl

Słowa kluczowe: $M$. hominis, M. genitalium, U. paroum, U. urealyticum, PCR, Mycoplasma IST2

Skróty: AZI - azytromycyna; CIP - ciprofloksacyna; CLA - klarytromycyna; DOT - doksycyklina; ERY - erytromycyna, JOS - josamycyna; OFL - ofloksacyna; Mh - Mycoplasma hominis; PRI - pristinamycyna; TET - tetracyklina; Uu - Ureaplasma spp.;

Podziękowania: Badania te były częściowo wspierane przez Wojewódzki Fundusz Ochrony Środowiska i Gospodarki Wodnej w Zielonej Górze. 
beta-laktamowych. Gotowe zestawy do identyfikacji mykoplazm koncentrują się na $M$ hominis i Ureaplasma spp. W związku z tym inne patogenne gatunki mykoplazm, np. M. genitalium, nie są wykrywane w standardowych testach i wymagają odrębnych metod diagnostycznych [15].

Diagnostyka molekularna, oparta o techniki PCR, jest istotną alternatywą dla testów biochemicznych, ze względu na możliwość identyfikacji poszczególnych gatunków mykoplazm. Literatura dostarcza informacji na temat różnych starterów, które są konstruowane w celu identyfikacji tych drobnoustrojów. Primery te koncentrują się na różnych celach molekularnych w genomie Mycoplasmatales. Niestety jak dotąd nie ustalono jednej czułej i swoistej metody identyfikacji poszczególnych gatunków w obrębie tej rodziny. Pewna detekcja poszczególnych gatunków Mycoplasma spp. i Ureaplasma spp. jest istotna przede wszystkim ze względu na ciągle niejasną rolę mykoplazm w patogenezie chorób układu moczo-płciowego $[16,17]$.

W Polsce wykrywanie mykoplazm urogenitalnych nie jest częścią rutynowej procedury diagnostycznej. W związku z tym niewiele wiadomo na temat stopnia nosicielstwa tych bakterii $\mathrm{w}$ polskiej populacji. W ostatnim czasie w Klinice Położnictwa i Ginekologii Szpitala Uniwersyteckiego w Zielonej Górze wprowadzono rutynowe badanie w kierunku obecności mykoplazm w wymazach z pochwy wszystkich pacjentek przyjmowanych na oddział. Diagnostyka opiera się o testy komercyjne identyfikujące dwa najpowszechniejsze gatunki mykoplazm. W związku z doniesieniami wskazującymi na różnice w wykrywaniu Mycoplasma spp. i Ureaplasma spp. gdy stosuje się metody hodowli i PCR [18-20], podjęto próbę porównania wydajności metody opartej na hodowli w stosunku do identyfikacji mykoplazm urogenitalnych w próbkach klinicznych metodami molekularnymi.

\section{MATERIAEY I METODY}

Analizie poddano 407 wymazów z pochwy, pobieranych rutynowo od pacjentek hospitalizowanych w Szpitalu Uniwersyteckim im. K. Marcinkiewicza w Zielonej Górze. Pobór prób odbywa się zawsze według ustalonych i ujednoliconych zasad, minimalizujących ewentualne błędy diagnostyczne.

W pierwszym etapie obecność mykoplazm urogenitalnych potwierdzano $\mathrm{w}$ laboratorium diagnostycznym Szpitala Uniwersyteckiego w Zielonej Górze. Test diagnostyczny przeprowadzono z wykorzystaniem zestawu Mycoplasma IST2 (bioMerieux), który identyfikuje Mycoplasma hominis i Ureaplasma spp. oraz umożliwia określenie przybliżonej ich liczby $\left(>10^{4}\right)$. Test dodatkowo ocenia lekowrażliwość izolatu wobec 9 antybiotyków / chemioterapeutyków. Mycoplasma IST2 przeprowadza się na pasku diagnostycznym ze studzienkami. W pożywce obecna jest arginina do hodowli mykoplazm i mocznik do hodowli ureaplazm oraz czerwień fenolowa jako wskaźnik zmiany $\mathrm{pH}$.

\section{$1 \mathrm{a}$}

wymaz

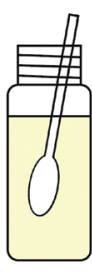

R1

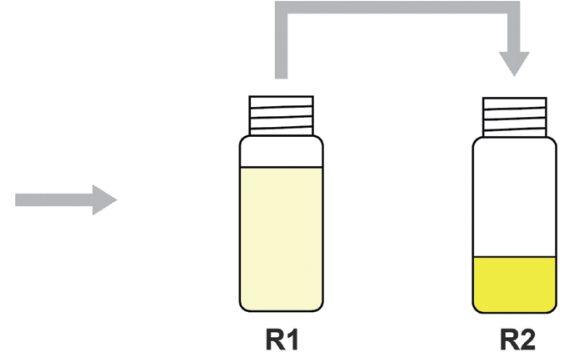

$1 b$

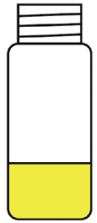

R1 + R2

1c

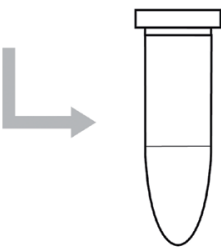

izolacja DNA -> PCR -> identyfikacja $U$. urealyticum, U. parvum, M. hominis, M. genitalium

Rycina 1. Procedura wykrywania mykoplazm urogenitalnych z wykorzystaniem Mycoplasma IST 2

Próbki kliniczne inokulowano do podłoża transportowego R1 zgodnie z instrukcjami producenta (Ryc. 1a), następnie przesiewano do zliofilizowanego podłoża wzrostowego R2 i otrzymaną zawiesinę przenoszono do studzienek na pasku diagnostycznym (Ryc. 1b). Próbki (pasek i pozostałość podłoża R1+R2) inkubowano w temperaturze $37^{\circ} \mathrm{C}$ i obserwowano zmiany barwy, spowodowane alkalizacją pożywki, od żółtego do czerwonego, po 24 i 48 godzinach inkubacji. Obecność M. hominis i Ureaplasma spp. rozpoznawano na podstawie zmiany barwy podłoża w odpowiednich studzienkach (interpretacja wyniku - tabela 1 i 2). W tym etapie zebrano 100 próbek pozytywnych.

Próby dodatnie w teście Mycoplasma IST2 (100 $\mu$ l hodowli w podłożu R1+R2 w trzech powtórzeniach) przesiewano na podłoże stałe A7 Mycoplasma Agar (bioMerieux) i inkubowano $\mathrm{w} 37^{\circ} \mathrm{C} \mathrm{w}$ warunkach mikroaerofil-

Tabela 1. Odczyt i interpretacja wyników hodowli w podłożu płynnym R1+R2.

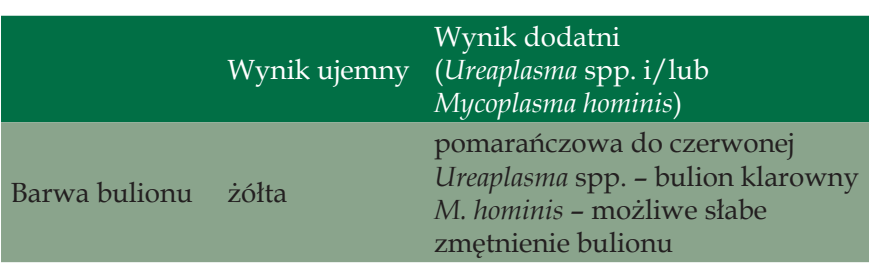


Tabela 2. Odczyt i interpretacja wyników hodowli na pasku Mycoplasma IST2.

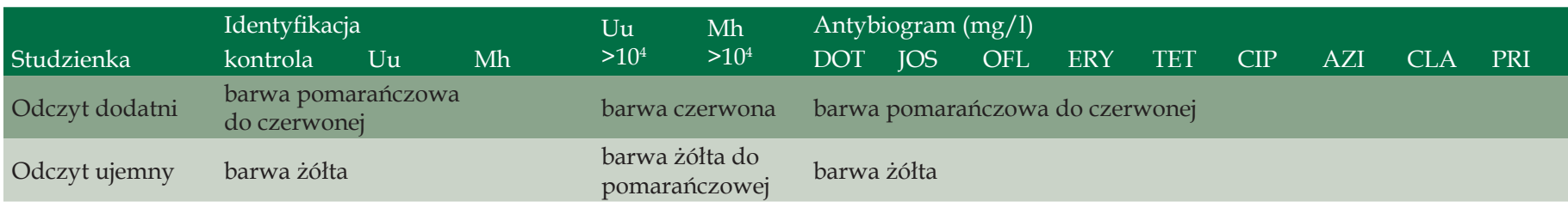

Tabela 3. Startery stosowane do wykrywania M. hominis, M. genitalium U. paroum i U. urealyticum metodą PCR.

\begin{tabular}{|c|c|c|c|c|}
\hline Specyficzność & Starter & Cel/ sekwencja & Wielkość amplikonu (pz) & Ref. \\
\hline Mycoplasma spp. & $\begin{array}{l}\text { GSO } \\
\text { MGSO }\end{array}$ & $\begin{array}{l}\text { 16S rRNA } \\
\text { GGGAGCAAACAGGATTAGATACCCT } \\
\text { TGCACCATCTGTCACTCTGTTAACCTC }\end{array}$ & 163 & 21 \\
\hline Ureaplasma spp. & $\begin{array}{l}\text { UuF5' } \\
\text { UuR5' }\end{array}$ & $\begin{array}{l}\text { 16S rRNA } \\
\text { TGGAGTTAAGTCGTAACAAG } \\
\text { CTGAGATGTTTCACTTCACC }\end{array}$ & 559 & 22 \\
\hline M. hominis & $\begin{array}{l}\text { RNA H1 } \\
\text { RNA H2 }\end{array}$ & $\begin{array}{l}\text { 16S rRNA } \\
\text { CAATGGCTAATGCCGGATACGC } \\
\text { GGTACCGTCAGTCTGCAAT }\end{array}$ & 344 & 23 \\
\hline M. genitalium & $\begin{array}{l}\text { MgPa-1 } \\
\text { MgPa-2 }\end{array}$ & $\begin{array}{l}\text { Gen adhezyny } \\
\text { AGTTGATGAAACCTTAACCCCTTGG } \\
\text { GACCATCAAGGTATTTCTCAACAGC }\end{array}$ & 282 & 24 \\
\hline U. parvum & $\begin{array}{l}\text { UP063\#1F } \\
\text { UP063\#1R }\end{array}$ & $\begin{array}{l}\text { Gen białka UP063 } \\
\text { TGCGGTGTTGTGAACT } \\
\text { TGATCAAACTGATATCGCAATTATAGA }\end{array}$ & 152 & 25 \\
\hline U. urealyticum & $\begin{array}{l}\text { UU127\#1F } \\
\text { UU127\#1R }\end{array}$ & $\begin{array}{l}\text { Gen białka UU127 } \\
\text { GGATTTTTAGATATCGTCAAGG } \\
\text { TCATCTTTTAAAGCTCCACATTATTAGT }\end{array}$ & 152 & 25 \\
\hline
\end{tabular}

nych. Wzrost kolonii oceniano mikroskopowo po 3 i 5 dniach inkubacji.

W dalszej części badań, wszystkie próbki Mycoplasma IST2-pozytywne poddawane były analizie molekularnej, w oparciu o konwencjonalny PCR (Ryc. 1c). Izolację DNA $\mathrm{z}$ osadu hodowli bulionowej R1+R2 Mycoplasma IST2 przeprowadzono z wykorzystaniem zestawu Wizard SV Genomic DNA Purification System (Promega) zgodnie $\mathrm{z}$ instrukcjami producenta. Badania molekularne wykonano w dwóch etapach. W pierwszej kolejności w próbkach identyfikowano rodzaje Mycoplasma i Ureaplasma wykorzystując startery celujące w sekwencje 16S rRNA. Następnie próbki z pozytywnymi wynikami dla rodzaju Ureaplasma analizowano pod kątem obecności $U$. urealyticum i $U$. paroum, a te pozytywne dla rodzaju Mycoplasma pod kątem obecności M. hominis i M. genitalium. Listę wykorzystanych starterów przedstawiono $\mathrm{w}$ tabeli 3. Skład reakcji PCR oraz warunki amplifikacji stosowano zgodnie $\mathrm{z}$ danymi literaturowymi [21-25]. Produkty PCR poddano elektroforezie w 2\% żelu agarozowym i identyfikowano na podstawie wielkości prążka (na podstawie danych literaturowych - tabela 3).

Wszystkie procedury przeprowadzone w tym badaniu były zgodne ze standardami etycznymi. Badanie to zostało zatwierdzone przez komisję bioetyki przy Okręgowej Izbie Lekarskiej w Zielonej Górze (No. 22/104/2018).

\section{WYNIKI}

W pierwszym etapie pracy potwierdzono obecność mykoplazm urogenitalnych w 100 próbkach klinicznych z wykorzystaniem zestawu Mycoplasma IST2, co stanowi $24,6 \%$. W teście tym, we wszystkich analizowanych próbkach, oznaczono jedynie Ureaplasma spp. Interpretacja wyniku hodowli IST2 potwierdziła obecność ureaplazm w próbach w ilości $>10^{4}$.

Hodowla na agarze A7 była pozytywna dla 26 próbek. W przypadku 5 hodowli wyniku nie można było zinterpretować, ze względu na obecność zanieczyszczeń i wzrost innych drobnoustrojów. Na podstawie charakterystycznej morfologii kolonii przypominającej "sadzone jajka” dla Mycoplasma spp. (Fot. 1) lub „jeżowce” dla Ureaplasma spp. zidentyfikowano odpowiednio 20 i 6 izolatów.

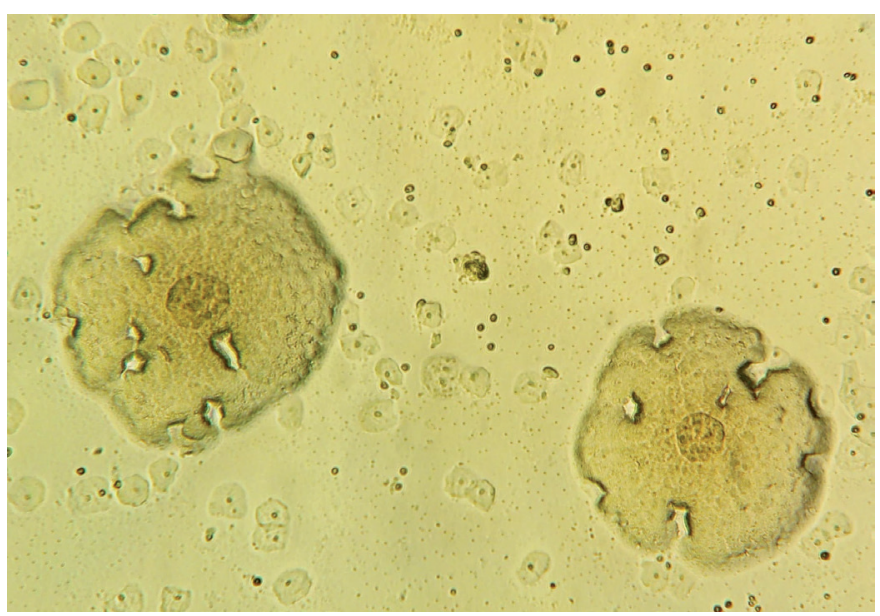

Fotografia 1. Mycoplasma spp. izolowana na agarze A7. 
Tabela 4. Porównaniu wyników hodowli i wyników PCR badanych prób.

$\begin{array}{llll}\text { Gatunek } & \text { IST2 } & \text { A7 } & \text { PCR } \\ \text { U. urealyticum } & - & - & 41 \\ \text { U. paroum } & - & - & 90 \\ \text { Ureaplasma spp. } & 100 & 20 & 100 \\ \text { M. hominis } & 0 & - & 49 \\ \text { M. genitalium } & - & - & 0 \\ \text { Mycoplasma spp. } & - & 6 & 99\end{array}$

W drugim etapie oceniano obecność mykoplazm urogenitalnych $\mathrm{w}$ badanych próbkach $\mathrm{z}$ wykorzystaniem konwencjonalnej reakcji PCR. Amplifikacja potwierdziła obecność rodzaju Ureaplasma we wszystkich próbach oraz rodzaju Mycoplasma w 99/100 próbach. Analiza szczegółowa z wykorzystaniem starterów specyficznych dla gatunku potwierdziła obecność U. urealyticum w 41/100 próbach $(41 \%)$ oraz U. parvum w 90/100 próbach $(90 \%)$. M. hominis stwierdzono w $49 / 99$ próbach $(49,5 \%)$. W pozostałych 50 próbach PCR-pozytywnych dla rodzaju Mycoplasma nie zidentyfikowano gatunku. Wyniki podsumowano w tabeli 4. Współwystępowanie dwóch lub trzech różnych gatunków mykoplazm urogenitalnych wykazano w większości (99/100) próbek (Tab. 5).

Tabela 5. Współwystępowanie mykoplazm urogenitalnych w badanych próbach

\begin{tabular}{ll}
\hline Gatunek & Liczba (\%) \\
U. paroum & $1(1 \%)$ \\
\hline U. paroum + M. hominis & $24(24 \%)$ \\
\hline U. urealyticum + M. hominis & $5(5 \%)$ \\
U. paroum + Mycoplasma spp. & $33(33 \%)$ \\
U. urealyticum + Mycoplasma spp. & $5(5 \%)$ \\
U. paroum + U. urealyticum + M. hominis & $20(20 \%)$ \\
\hline U. paroum + U. urealyticum + Mycoplasma spp. & $12(12 \%)$ \\
\hline Łącznie & $100(100 \%)$
\end{tabular}

Porównanie wyników testu biochemicznego z wykorzystaniem zestawu Mycoplasma IST2, hodowli na agarze A7 oraz testu molekularnego PCR wskazuje na ich niezgodność. Zestaw komercyjny IST2 wykazał obecność $\mathrm{w}$ analizowanych próbach jedynie Ureaplasma spp., nie potwierdził natomiast obecności Mycoplasma spp. Hodowla na podłożu stałym A7 potwierdziła obecność obu rodzajów identyfikowanych drobnoustrojów, jednak ze znacznie niższą czułością. Badania molekularne potwierdziły obecność rodzaju Mycoplasma w analizowanym materiale (99/100), przy czym obecność gatunku M. hominis potwierdzono w prawie połowie prób (49,5\%).

\section{DYSKUSJA}

Według danych literaturowych występowanie mykoplazm urogenitalnych zależy od wielu czynników tj. wiek, aktywność seksualna, poziom hormonów czy ciąża. Dlatego też rozkład stopnia nosicielstwa waha się w du- żym zakresie, w zależności od grupy badanej [26,27]. Nasze wyniki, dotyczące kolonizacji Ureaplasma spp. 24,6\% badanych kobiet, są zgodne z niektórymi autorami, którzy wykazali podobny procent kolonizacji [28-30] oraz wynikami nielicznych badań prowadzonych w Polsce, które pokazują 29,8\% przypadków Ureaplasma spp. u kobiet nie będących w ciąży z infekcją układu moczo-płciowego oraz 26,3\% w przypadku kobiet w ciąży [3132]. Z drugiej jednak strony jest wiele doniesień wykazujących poziom nosicielstwa rzędu 40-70\% [33-36]. Tak duże rozbieżności danych potwierdzają, że na wynik analizy wpływ ma przede wszystkich wybór grupy badanej. Dane literaturowe, również te z Polski, dotyczące Mycoplasma spp., głównie M. hominis, mówią o stopniu kolonizacji na poziomie 7-27\% [37-40]. Pokrywa się to z naszymi wynikami, jednakże w większości naszych prób (99\%) wykazaliśmy współwystępowanie Mycoplasma spp. z Ureaplasma spp., co jest zjawiskiem powszechnym i już opisywanym w literaturze [41-44], jednak jak dotąd nie odnotowano tak wysokiego stopnia koinfekcji.

Bezpośrednia detekcja mykoplazm urogenitalnych w próbkach klinicznych jest niemożliwa, ze względu na ich właściwości tj. małe rozmiary i brak ściany komórkowej. Za złoty standard w ich wykrywaniu uznawana jest ciągle hodowla, jednak analiza DNA pozwala na identyfikację poszczególnych gatunków mykoplazm [45].

Przeprowadzone badania wykazały, że wyniki detekcji mykoplazm urogenitalnych z wykorzystaniem zestawu Mycoplasma IST2 (markery biochemiczne), hodowli na agarze A7 oraz PCR (stosując startery specyficzne dla gatunków z rodzaju Mycoplasma i Ureaplasma) są niezgodne. Hodowla w podłożu płynnym zestawu IST2 i na podłożu stałym, okazuje się mniej czuła i mało specyficzna. Komercyjny zestaw stosowany w szpitalnym laboratorium diagnostycznym potwierdza obecność mykoplazm urogenitalnych w próbkach klinicznych, ale wyniki te nie korespondują w wynikami analiz genetycznych. Zestaw IST2 identyfikuje jedynie rodzaj Ureaplasma, jak jednak wskazuje analiza molekularna, na podłożu wykorzystywanym do identyfikacji wzrasta zarówno uznawany za patogenny U. urealyticum, jak również $U$. paroum, który nie jest uznawany za gatunek chorobotwórczy. Jak pokazują nasze wyniki $U$. parvum jest identyfikowane metodami molekularnymi znacznie częściej albo jako jedyny izolat w próbie, albo też współwystępuje on z U. urealyticum. Wyjaśnienie tego jest proste. U. urealyticum po raz pierwszy wyizolowano w 1954 r., zaś rodzaj Ureaplasma ustanowiono w 1974 r. Do roku 2002 U. urealyticum uważano za jedyny gatunek tego rodzaju, o którym wiadomo było, że może zakażać ludzi. W obrębie gatunku wyróżniono 14 serowarów, jednak analiza genetyczna i klasyfikacja na podstawie sekwencji genów 16S rRNA potwierdziły odrębność części serowarów i tak serotypy 1, 3, 6 i 14 sklasyfikowano jako nowy gatunek Ureaplasma parvum, podczas gdy U. urealyticum obejmuje pozostałe 10 serotypów [46]. Gatunki te jednak pod względem morfologii i fizjologii są nieodróżnialne, zatem test biochemiczny nie pozwala na przypisanie izolatu do gatunku, a jedynie do rodzaju Ureaplasma, a jedyny sposób rozróżnienia gatunków to analiza genetyczna. Taki stan rzeczy wydaje się pro- 
blematyczny z klinicznego punktu widzenia, ponieważ w przypadku dodatniego wyniku testu biochemicznego nie wiadomo czy do czynienia mamy z kolonizacją czy już z zakażeniem. Rodzi się zatem pytanie czy pacjentki z dodatnim testem Ureaplasma spp. należy leczyć czy też u każdej takiej pacjentki powinno się potwierdzać obecność U. urealyticum w dodatkowym teście molekularnym?

W przeprowadzonych analizach nie potwierdzono obecności $M$. genitalium, prawdopodobnie ze względu na dużą wrażliwość tego gatunku na warunki środowiskowe i jego zmniejszoną żywotność w hodowli. Zaskakujące są natomiast wyniki identyfikujące $M$. hominis. Zestaw Mycoplasma IST2 nie potwierdza obecności tego gatunku w analizowanych próbach, natomiast w 20 przypadkach wzrost Mycoplasma spp. zaobserwowano na podłożu stałym A7. Ich obecność potwierdziła także analiza genetyczna. Rodzaj Mycoplasma zidentyfikowano w 99/100 próbach, a gatunek $M$. hominis oznaczono w 49,5\% tych prób. Rozbieżności wyników uzyskanych metodami hodowlanymi przypisać można, przynajmniej częściowo, ogólnie uznawanym trudnościom w hodowli i izolowaniu mykoplazm, ale być może także istotny jest czas inkubacji prób w przypadku zestawu Mycoplasma IST2 [47]. $M$. hominis jest gatunkiem, którego czas generacji wynosić może kilka godzin. Niewielka liczba komórek w materiale klinicznym może skutkować wydłużonym czasem potrzebnym do osiągnięcia gęstości hodowli wpływającej na zmianę $\mathrm{pH}$ pożywki i tym samym widoczną zmianę jej zabarwienia. Zatem krótki czas inkubacji zestawu IST2 może wpływać na uzyskanie wyniku fałszywie ujemnego. Mała liczbę prób dodatnich na podłożu stałym A7 tłumaczyć można natomiast tym, że próbki były na nie przesiewane dopiero $\mathrm{z}$ podłoża R1+R2 zestawu IST2, a nie bezpośrednio z materiału klinicznego, co mogło znacząco wpłynąć na żywotność mykoplazm. Rozważając przyczyny rozbieżności wyników hodowli i badań molekularnych należy też brać pod uwagę fakt, że PCR wykrywa obecność DNA w niewielkich ilościach, ale także DNA martwych organizmów oraz tylko jego fragmenty. W hodowli natomiast niezbędne są żywe komórki zdolne do podziałów, zatem zbyt mała ich liczba albo też brak ich zdolności do namnażania może dawać wynik ujemny w hodowli.

Pomimo potwierdzenia obecności Mycoplasma spp. w prawie wszystkich próbach (99/100), w 50 przypadkach nie udało się zidentyfikować gatunku. Świadczyć to może albo o zbyt małej specyficzności zastosowanych starterów PCR, albo obecności gatunku innego niż poszukiwane M. hominis i M. genitalium.

Zwiększona czułość w wykrywaniu mykoplazm za pomocą PCR jest zgodna z literaturą [48-49], co nie jest zaskakujące, biorąc pod uwagę fakt, że mykoplazmy są organizmami pozbawionymi ściany komórkowej i bardzo wrażliwymi na warunki środowiskowe. Jak dotąd nie wykazano jednak tak dużej rozbieżności $\mathrm{w}$ ocenie obecności M. hominis metodami hodowlanymi i molekularnymi.
Współwystępowanie kilku gatunków mykoplazm urogenitalnych w narządach moczo-płciowych ludzi jest powszechne jak wskazują np. Taylor-Robinson i Jensen (2010). W analizowanych próbkach test IST2 nie wykazał jednak tego zjawiska. Potwierdziły to dopiero analizy molekularne. PCR pokazał obecność Mycoplasma spp. wraz z U. paroum i/lub U. urealyticum w prawie wszystkich próbkach (99/100). Wyniki te są zgodne z danymi literaturowymi, jednak do tej pory nikt nie zgłosił obecności dwóch/ trzech różnych gatunków mykoplazm urogenitalnych w tak dużej liczbie badanych prób.

Zdolność do różnicowania mykoplazm i ureaplazm w próbkach klinicznych nadal stanowi wyzwanie dla diagnostów i badaczy. Rozróżnianie U. urealyticum i U. paroum wydaje się szczególnie zasadne zakładając, że to ten pierwszy gatunek stanowi czynnik etiologiczny zakażeń układu moczo-płciowego. W związku z zaobserwowanym stanem rzeczy właściwe wydaje się stosowanie testu diagnostycznego opartego na hodowli jedynie w celach przesiewowych albo też łączenie metod hodowlanych i molekularnych w identyfikacji mykoplazm urogenitalnych oraz sprawdzanie pod katem ich obecności również prób ujemnych $\mathrm{w}$ hodowli, jeśli objawy kliniczne badanej pacjentki wskazują na możliwy udział drobnoustrojów atypowych w infekcji. Uzasadniona byłaby też próba podjęcia opracowania metody potwierdzającej obecność mykoplazm w sposób pewny i niezawodny. Najbardziej właściwym wydaje się w tej sytuacji zastosowanie nowocześniejszych i czulszych technik molekularnych, takich jak Real-Time PCR, który daje również możliwość jednoczesnego oceniania ilościowego materiału.

\section{PIŚMIENNICTWO}

1. Razin S, Yogev D, Naot Y (1998) Molecular biology and pathogenicity of mycoplasmas. Microb Mol Biol Rev 62: 1094-156

2. International Committee on Systematic Bacteriology-Subcommittee on the Taxonomy of Mollicutes. Revised minimum standards for description of new species of the class Mollicutes (Division Tenericutes) (1995) Int J Syst Bacteriol 45: 605-612

3. Waites KB, Katz B, Schelonka RL (2005) Mycoplasmas and ureaplasmas as neonatal pathogens. Clin Microbiol Rev 18: 757-789

4. Uuskula A, Kohl PK (2002) Genital mycoplasmas, including Mycoplasma genitalium, as sexually transmitted agents. International Journal of STD \& AIDS 13: 79-85

5. Novy MJ, Duffy L, Axthelm MK (2009) Ureaplasma paroum or Mycoplasma hominis as sole pathogens cause chorioamnionitis, preterm delivery, and fetal pneumonia in rhesus macaques. Reprod Sci, 16 (1): 56-70

6. Sanchez PJ, Regan JA (1990) Vertical transmission of Ureaplasma urealyticum from mothers to preterm. Pediatr Infect Dis J, 9: 398-401

7. Kim Y, Kim J, Lee KA (2014) Prevalence of sexually transmitted infections among healthy Korean women: implications of multiplex PCR pathogen detection on antibiotic therapy. J Infect Chemother 20: 74-76

8. Leli C, Mencacci A, Latino MA (2017) Prevalence of cervical colonization by Ureaplasma paroum, Ureaplasma urealyticum, Mycoplasma hominis and Mycoplasma genitalium in childbearing age women by a commercially available multiplex realtime PCR: An Italian observational multicentre study. J Microbiol Immunol Infect 17: 30091-30099

9. Esen B, Gozalan A, Sevindi DF (2017). Ureaplasma urealyticum: presence among sexually transmitted diseases. Jpn J Infect Dis 70: 75-79

10. Marovt M, Kese D, Kotar T (2015). Ureaplasma parvum and Ureaplasma urealyticum detected with the same frequency among women with and 
without symptoms of urogenital tract infection. Eur J Clin Microbiol Infect Dis 34: 1237-1245

11. Lobao TN, Campos GB, Selis NN (2017) Ureaplasma urealyticum and $U$. paroum in sexually active women attending public health clinics in Brazil. Epidemiol Infect 145: 2341-2351

12. Kyndel A, Elmer C, Kallman O, Altman D (2016) Mycoplasmataceae colonizations in women with urethral pain syndrome: A case-control study. J Low Genit Tract Dis 20: 272-274

13. Ouzounova-Raykova VV, Markovska R, Mizgova G, Mitov IG (2011) Detection of the sexually transmissible genital mycoplasmas by polymerase chain reaction in women. Sex Health 8: 445-446

14. Waites KB, Bebear CM, Robertson JA, Talkington DF, Kenny GE (2001) Laboratory diagnosis of mycoplasmal infections - Ed American Society for Microbiology, 1-30

15. Luki, N, Lebel P, Boucher M, Doray B, Turgeon J, Brousseau R (1998) Comparison of polymerase chain reaction assay with culture for detection of genital mycoplasmas in perinatal infections. Eur J Clin Microbiol Infect Dis 17: 255-263

16. Knox CL, Timms P (1998) Comparison of PCR, nested PCR, and random amplified polymorphic DNA PCR for detection and typing of Ureaplasma urealyticum in specimens from pregnant women. J Clin Microbiol 36: 3032-3039

17. Kong F, Ma Z, James G, Gordon S, Gilbert GL (2000) Species identification and subtyping of Ureaplasma paroum and Ureaplasma urealyticum using PCR-based assays. J Clin Microbiol 38: 1175-1179

18. Amirmozafari N, Mirnejad R, Kazemi B, Sariri E, Bojari MR, Darkahi FD (2009). Comparison of polymerase chain reaction and culture for detection of genital mycoplasmas in clinical samples from patients with genital infections. Saudi Med J 30: 1401-5

19. Stellrecht KA, Woron AM, Mishrik NG, Venezia RA (2004). Comparison of multiplex PCR assay with culture for detection of genital mycoplasmas. J Clin Microbiol 42: 1528-1533.

20. Frølund M, Björnelius E, Lidbrink P, Ahrens P, Jensen JS (2014). Comparison between culture and a multiplex quantitative real-time polymerase chain reaction assay detecting Ureaplasma urealyticum and $U$. paroum. PLoS One 21; 9 (7)

21. Férandon C., Peuchant O., Janis C., Benard A., Renaudin H., Pereyre S., Bébéar C (2011) Development of a real-time PCR targeting the yidC gene for the detection of Mycoplasma hominis and comparison with quantitative culture. Clin Microbiol Infect 17: 155-159

22. Irajian G, Sharifi M, Mirkalantari S, Mirnejad R, Jalali Nadoushan MR, GhorbanpourN (2016) Molecular detection of Ureaplasma urealyticum from prostate tissues using PCR-RFLP. Iran J Pathol 11: 138-143

23. Jamalizadeh Bahaabadi S, Mohseni Moghadam N, Kheirkhah B, Farsinejad A, Habibzadeh V (2014) Isolation and molecular identification of Mycoplasma hominis in infertile female and male reproductive system. Nephrourol Mon 6: e22390

24. Scov Jensen J, Uldum SA, Søndergård-Andersen J, Vuust J, Lind K (1991) Polymerase chain reaction for detection of Mycoplasma genitalium in clinical samples. J Clin Microbiol 29: 46-50

25. Xiao L, Glass JI, Paralanov V (2010) Detection and characterization of human Ureaplasma species and serovars by real-time PCR. J Clin Microbiol. 48: 2715-23

26. Taylor-Robinson D, Jensen JS (2010) Genital mycoplasmas. In: Morse SA et al. (eds). Atlas of sexually transmitted diseases and AIDS. 4th edn. Elsevier, pp. 64-71.

27. Remington J, Klein J, Wilson C, Nizet V, Maldonado Y (2010) Mycoplasmal infections. In: Infectious Diseases of the Fetus and Newborn. Elsevier Saunders, Amsterdam

28. Kafetzis DA, Skevaki CL, Skouteri V, Gavrili S, Peppa K, Kostalos C, Petrochilou V, Michalas S (2004) Maternal genital colonization with Ureaplasma urealyticum promotes preterm delivery: association of the respiratory colonization of premature infants with chronic lung disease and increased mortality. Clin Infect Dis 39: 1113-1122

29. González Bosquet E, Gené A, Ferrer I, Borrás M, Lailla JM (2006) Value of endocervical Ureaplasma species colonization as a marker of preterm delivery. Gynecol Obstet Invest 61: 119-123
30. Lukic A, Canzio C, Patella A, Giovagnoli M, Cipriani P, Frega A, Moscarini M (2006) Determination of cervicovaginal microorganisms in women with abnormal cervical cytology: the role of Ureaplasma urealyticum. Anticancer Res 26: 4843-4849

31. Zdrodowska-Stefanow B, Kłosowska WM, Ostaszewska-Puchalska I, Bułhak-Kozioł V, Kotowicz B (2006) Ureaplasma urealyticum and Mycoplasma hominis infection in women with urogenital diseases. Adv Med Sci 51: 250-253

32. Kalinka J, Krajewski P, Sobala W, Wasiela M, Brzezińska-Błaszczyk E (2006) The association between maternal cervicovaginal proinflammatory cytokines concentrations during pregnancy and subsequent early-onset neonatal infection. J Perinat Med 34: 371-377

33. Povlsen K, Jensen JS, Lind I (1998) Detection of Ureaplasma urealyticum by PCR and biovar determination by liquid hybridization. J Clin Microbiol 36: 3211-216

34. Abele-Horn M, Wolff C, Dressel P, Pfaff F, Zimmermann A (1997) Association of Ureaplasma urealyticum biovars with clinical outcome for neonates, obstetric patients, and gynecological patients with pelvic inflammatory disease. J Clin Microbiol 35: 1199-1202

35. Sleha R, Boštíková V, Hampl R (2016) Prevalence of Mycoplasma hominis and Ureaplasma urealyticum in women undergoing an initial infertility evaluation. Epidemiol Mikrobiol Imunol 65: 232-237

36. Grattard F, Soleihac B, De Barbeyrac B, Bebear C, Seffert P, Pozzetto B (1995) Epidemiologic and molecular investigations of genital mycoplasmas from women and neonates at delivery. Pediatr Infect Dis J 14: 853-858

37. Friedek D, Ekiel A, Chelmicki Z, Romanik M (2004) HPV, Chlamydia trachomatis and genital mycoplasmas infections in women with lowgrade squamous intraepithelial lesions (LSIL). Ginekol Pol 75: 457-463.

38. Friedek D, Ekiel A, Romanik M, Chelmicki Z, Wiechula B, Wilk I, Józwiak J, Martirosian G (2005) Co-occurrence of urogenital mycoplasmas and group B streptococci with chlamydial cervicitis. Pol J Microbiol 54: 253-255

39. Zdrodowska-Stefanow B, Kłosowska WM, Ostaszewska-Puchalska I Bułhak-Kozioł V, Kotowicz B (2006) Ureaplasma urealyticum and Mycoplasma hominis infection in women with urogenital diseases. Adv Med Sci 51: 250-253

40. Ekiel AM, Friedek DA, Romanik MK, Jóźwiak J, Martirosian G (2009) Occurrence of Ureaplasma paroum and Ureaplasma urealyticum in women with cervical dysplasia in Katowice, Poland. J Korean Med Sci 24: 1177-1181

41. Horváth B, Turay A, Lakatos F, Végh G, Illei G (1989 Incidence of Mycoplasma hominis and Ureaplasma urealyticum infection in pregnanat women and gynaecological patients. The effecticity of Doxycylin therapy. Therapia Hung 37: 23

42. Katz B, Patel P, Duffy L, Schelonka RL, Dimmitt RA, Waites KB (2005) Characterization of ureaplasmas isolated from preterm infants with and without bronchopulmonary dysplasia. J Clin Microbiol. 43: 48524854

43. Rastawicki W, Kalota H, Jagielski M, Gierczyński R (2004) Comparison of polymerase chain reaction assay and Mycoplasma IST 2 test with culture for detection of infections caused by Ureaplasma urealyticum and Mycoplasma hominis. Med Dosw Mikrobiol 56: 99-108

44. Yokoi S, Maeda S, Kubota Y, Tamaki M, Mizutani K, Yasuda M, Ito S, Nakano M, Ehara H, Deguchi T (2007) The role of Mycoplasma genitalium and Ureaplasma urealyticum biovar 2 in postgonococcal urethritis. Clin Infect Dis 45: 866-871

45. Waites KB., Taylor-Robinson D (2011) Mycoplasma and Ureaplasma. In: Versalovic J, Carroll K, Funke G, Jorgensen J, Landry M, Warnock DW, eds. Manual of Clinical Microbiology. 10 edn, pp 970-985. ASM Press; Washington, DC

46. Robertson JA, Stemke GW, Davis Jr. JW (2002) Proposal of Ureaplasma paroum sp. nov. and emended description of Ureaplasma urealyticum (Shepard et al., 1974) Int J Syst Evol Microbiol 52: 587-597

47. Robertson J, Gomersall M, Gill P (1975) Mycoplasma hominis: growth, reproduction, and isolation of small viable cells. J Bacteriol 124: 10071018 
48. Jamalizadeh Bahaabadi S, Mohseni Moghadam N, Kheirkhah B, Farsinejad A, Habibzadeh V (2014) Isolation and molecular identification of Mycoplasma hominis in infertile female and male reproductive system. Nephrourol Mon 6: e22390
49. de Francesco MA, Negrini R, Pinsi G, Peroni L, Manca N (2009) Detection of Ureaplasma biovars and polymerase chain reaction-based subtyping of Ureaplasma paroum in women with or without symptoms of genital infections. Eur J Clin Microbiol Infect Dis 6: 641-645

\title{
Detection of urogenital mycoplasmas in clinical samples
}

\section{Sylwia Andrzejczak-Grządko ${ }^{1 凶}$, Izabela Dolińska ${ }^{2}$}

${ }^{1}$ Department of Microbiology and Genetics, Faculty of Biological Sciences, University of Zielona Góra

${ }^{2}$ Department of Laboratory Diagnostics, K. Marcinkowski University Hospital in Zielona Góra

$\square_{\text {corresponding author: s.andrzejczak-grzadko@wnb.uz.zgora.pl }}$

Key words: M. hominis, M. genitalium, U. paroum, U. urealyticum, PCR, Mycoplasma IST2

\begin{abstract}
Urogenital mycoplasmas belonging to Mycoplasma and Ureaplasma genera, are both commensal and pathogenic microorganisms. The gold standard for their detection in clinical samples is culture and identification based on biochemical tests. However, this method is time-consuming and not very specific. Detection of mycoplasmas using PCR allows for assigning not only to the genus, but also to the species. In this study, 100 clinical samples were analyzed to identify M. hominis, M. genitalium, U. parvum and U. urealyticum, using both biochemical and molecular methods. The presented results confirm the low specificity of biochemical tests and the higher detection efficiency of individual species using molecular methods.
\end{abstract}

